JMI Vol. 41 No. 2, Desember 2019

METAL INDONESIA
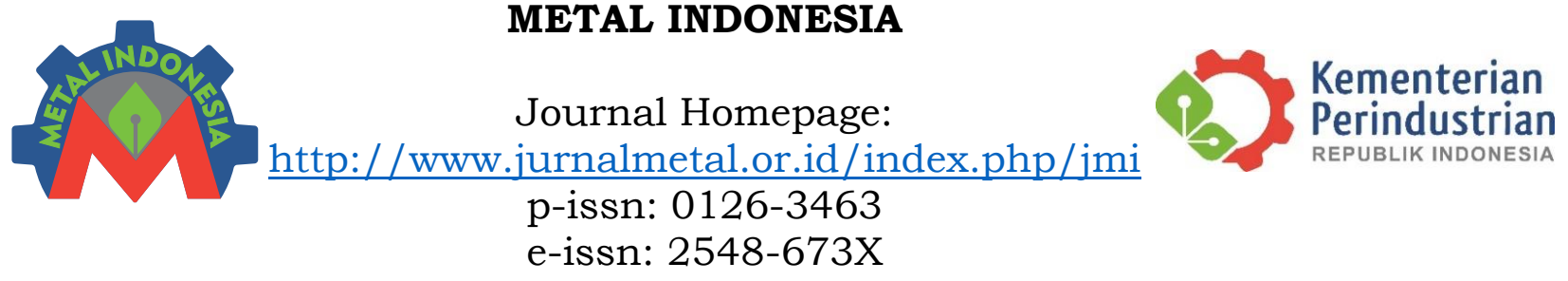

\title{
MICROSTRUCTURE AND HARDNESS PROFILE OF DISSIMILAR LAP JOINT OF TYPE 304 STAINLESS STEEL TO SS400 CARBON STEEL
}

\author{
Herry Oktadinata ${ }^{1}$ and Adi Ganda Putra ${ }^{2}$ \\ ${ }^{1,2}$ Mechanical Engineering Dept., Universitas Jenderal Achmad Yani, Bandung, Indonesia

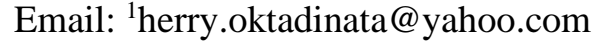

\begin{abstract}
Dissimilar metal welds between austenitic stainless steel and carbon steel are commonly used in oil and gas industries for certain reasons. The objective of this research is to asses the effect of filler metal and shielding gas on the microstructure and hardness of dissimilar lap joint of type 304 austenitic stainless steel to JIS SS400 low carbon steel. For the purpose of this investigation, the weldments were produced using flux-cored arc welding (FCAW). Three types of filler metals (E316L, E309L and E308L) and two different gas compositions $\left(100 \% \mathrm{CO}_{2}\right.$ and $\left.90 \% \mathrm{Ar}+10 \% \mathrm{CO}_{2}\right)$ were selected to be used. Each of the weldments were analyzed on the microstructure characteristic and hardness profile of base metal (BM), heat affected zone (HAZ) and weld metal (WM) using optical microscope and microhardness Vickers. The metallographic examination revealed HAZ-SS400 contains martensites. Both HAZ-304 and WM show austenitic microstructure, with columnar and cellular sub-structures present at WM. The hardness profile of HAZ-304 is higher than BM-304, it may be attributed to the presence of the fine grains in HAZ-304 due to high temperature during welding. The hardness profile of WM-E309L exhibited the hardness from HAZ to WM tend to decrease linearly, while WM-E316L and WM-E308L showed the hardness from HAZ to WM also decreased but drastically dropped at fusion line (FL). The welds using E309L offer the best result in the point of view homogeneity of the hardness profile.
\end{abstract}

Keywords: dissimilar metal weld, 304 austenitic stainless steel, SS400 low carbon steel, hardness, microstructure

\section{INTRODUCTION}

The two main issues in dissimilar metal weld (DMW) between austenitic stainless steel and ferritic steel are the difference coefficient of thermal expansion and the sensitization phenomenon, carbon diffused from ferritic steel to austenitic stainless steel caused the hard phase of chromium carbides is developed. Stainless steels are commonly used in various applications due to good mechanical properties and corrosion resistance. In fabrication of pipe supports and sliding plates for liquid natural gas (LNG) plant, austenitic stainless steel and carbon steel need to be joined where they are used to support the stainless steel pipe on the ferritic steel structure. In this application, the austenitic stainless steel side of pipe support contacted to austenitic stainless steel pipe while the ferritic steel side of pipe support joined to ferritic steel structure. Cost reduction is the main reason for joining of DMW between stainless steel which have good corrosion but expensive and carbon steel which less corrosion resistance and cheap.

Fusion welding is a common process for joining components in steel fabrication including DMW of austenitic stainless steel to ferritic steel. Welding parameters (i.e. voltage, current, welding speed, filler metal, shielding gas composition, gas flow rate and welding method) are important that determine good quality welds in both microstructure and mechanical properties (Ramazan and Tümer 2013) (Costanza, Sili, and Tata 2016). A few studies on the evaluation of DMW between austenitic stainless steel and ferritic steel have 
been conducted in recent years.

Selection of appropriate filler metal is very important that influence quality of welds in DMW. The filler metal expected to overcome a mismatch in coefficient thermal expansion between austenitic stainless steel and ferritic steel, and also the carbon diffused from ferritic steel to austenitic stainless steel. M. Sireesha et al. (Sireesha et al. 2000) suggested using the nickel-base filler metal for the joint between alloy 800 and 316LN stainless steel due to it produced good mechanical properties and improved thermal stability. I. Hajiannia et.al (Hajiannia, Shamanian, and Kasiri 2013) investigated microstructure and mechanical properties of AISI 347 stainless steel and A335 low alloy steel welded by GTAW using ER309L and ERNiCr-3 filler metals. It was concluded that ERNiCr-3 is the best choice due to provide optimum mechanical properties.

Also A. Mortezaie et al. (Mortezaie and Shamanian 2014) studied microstructure and mechanical properties of $310 \mathrm{~S}$ stainless steel and Inconel 178 nickel-base superalloy welded by GTAW using three different filler metals (Inconel 625, Inconel 82 and 310SS). The results showed Inconel 82 offers the optimum properties at room temperature. H.S. Hosseini et al. (Hosseini, Shamanian, and Kermanpur 2016) showed nickel-base superalloy 617 (Inconel 617) filler metal provided better solidification cracking resistance compared to 310 stainless steel filler metal for DMW between Inconel 617 and 310 stainless steel.

Shielding gas composition that using during welding also plays an important role which affects the mechanical properties and metallurgy characteristic of steel welds. Pure $\mathrm{CO}_{2}$ is often selected for shielding gas due to its low cost and provides deep penetration, but the arc is less stable and more spatter is produced. On the other hand, pure argon produces a stable arc but it's expensive and narrow penetration. Therefore a mixture shielding gas is normally used for the best compromise. Argon with small amount of $\mathrm{CO}_{2}$ provides a good combination of weld penetration, arc stability and less spatter (Costanza, Sili, and Tata 2016). D. Katherasan et al. (Katherasan, Sathiya, and Raja 2013) reported toughness and ferrite percentage of steel weld were decreased with increasing $\mathrm{CO}_{2}$ in shielding gas mixture for $316 \mathrm{~L}$ stainless steel FCA welded with $316 \mathrm{~L}$ filler metal.

In this study, effect of filler metal type and shielding gas composition has been investigated on microstructure and hardness profile for dissimilar lap joint of type 304 austenitic stainless steel to JIS SS400 low carbon steel. The experimental design was performed to ensure the sufficient microstructure and mechanical properties of the weld metals are produced by the most appropriate filler metal and shielding gas.

\section{MATERIALS AND EXPERIMENTAL WORK}

In this welding experiment the two base metals, type 304 stainless steel and JIS SS400 carbon steel were supplied. Type 304 with 3 $\mathrm{mm}$ thickness and SS400 with $6 \mathrm{~mm}$ thickness were cut to the dimension of $90 \times 50 \times 3 \mathrm{~mm}^{3}$ and $120 \times 80 \times 6 \mathrm{~mm}^{3}$ respectively. In this work welding experiment was performed with Miller Delta Weld 451 machine. The stainless steel filler metal of $1.2 \mathrm{~mm}$ diameter was deposited on the dissimilar lap joint of type 304 and SS400 plates using multipass welding process by the FCAW method. Three types of filler metals (E316L, E309L and E308L) and two different gas compositions $\left(100 \% \mathrm{CO}_{2}\right.$, $90 \% \mathrm{Ar}+10 \% \mathrm{CO}_{2}$ ) were employed in these experiments. The chemical analysis of base metals and filler metals are presented in Table 1.

Table 1. Nominal chemical compositions (wt\%) of the base metals (from the test result) and filler metals (from the manufacturer)

\begin{tabular}{|c|c|c|c|c|c|c|c|c|c|c|c|c|c|}
\hline \multirow{2}{*}{$\begin{array}{l}\text { Base } \\
\text { metal } \\
\text { /filler } \\
\text { metal }\end{array}$} & \multicolumn{10}{|c|}{ Percentage composition (wt.\%) } & \multicolumn{3}{|c|}{$\begin{array}{c}\mathrm{Cr}_{\mathrm{eq}} \& \mathrm{Ni}_{\mathrm{eq}} \text { values } \\
\text { calculated }\end{array}$} \\
\hline & $\mathrm{C}$ & $\mathrm{Cr}$ & $\mathrm{Ni}$ & $\mathrm{Mn}$ & $\mathrm{Si}$ & $\mathrm{P}$ & $\mathrm{S}$ & Mo & $\mathrm{Cu}$ & $\mathrm{Fe}$ & $\mathrm{Cr}_{\mathrm{eq}}$ & $\mathrm{Ni}_{\mathrm{eq}}$ & $\begin{array}{l}\text { Creq / } \\
\mathrm{Ni}_{\text {eq }}\end{array}$ \\
\hline Type 304 & 0.025 & 18.2 & 8.36 & 1.18 & 0.338 & 0.019 & 0.005 & 0 & 0.089 & Bal. & 18.71 & 9.69 & 1.93 \\
\hline SS400 & 0.14 & 0.015 & 0 & 0.705 & 0.255 & 0.009 & 0.007 & 0 & 0.006 & Bal. & 0.40 & 4.55 & 0.09 \\
\hline E308L & 0.029 & 20.07 & 9.84 & 1.35 & 0.42 & 0.016 & 0.009 & 0.06 & 0.05 & Bal. & 20.76 & 11.39 & 1.82 \\
\hline E309L & 0.031 & 23.59 & 13.33 & 1.29 & 0.51 & 0.018 & 0.006 & 0.02 & 0.10 & Bal. & 24.38 & 14.91 & 1.64 \\
\hline E316L & 0.028 & 18.95 & 12.22 & 1.35 & 0.47 & 0.017 & 0.005 & 2.23 & 0.05 & Bal. & 21.89 & 13.74 & 1.59 \\
\hline
\end{tabular}


After welding experiments, the welded samples were transversally cut to obtain specimens for metallographic examination (Figure 1a-b). There were six specimens which represent the welded samples that produced by FCAW using combination of different filler metal type and different shielding gas (Table 2). Each specimen were mechanical mirror polished and chemical etched according to standard metallographic test procedure in order to observe microstructure. The carbon steel side on the specimens were etched using $2 \%$ nital solution $\left(2 \mathrm{ml} \mathrm{HNO}_{3}+98 \mathrm{ml}\right.$ etanol $)$ while stainless steel side using marble solution (10 gr $\mathrm{CuSO}_{4}+50 \mathrm{ml} \mathrm{HCl}+50 \mathrm{ml} \mathrm{H}_{2} \mathrm{O}$ ). Microscopic examination was performed by Nikon LV-150 optical microscope across the weld section to observe the microstructure of HAZ-304, WM and HAZ-SS400.

The microhardness Vickers tests were carried out to characterize their mechanical properties. Microhardness measurement was performed across the weld joint on $2 \mathrm{~mm}$ below the top surface using a microhardness Vickers tester (Zwick 3212). A load of $0.2 \mathrm{~kg}$ was employed for duration of $10 \mathrm{~s}$ on each indentation point. The indentation points were made along the BM-304, HAZ-304, WM, HAZ-SS400 and BM-SS400.
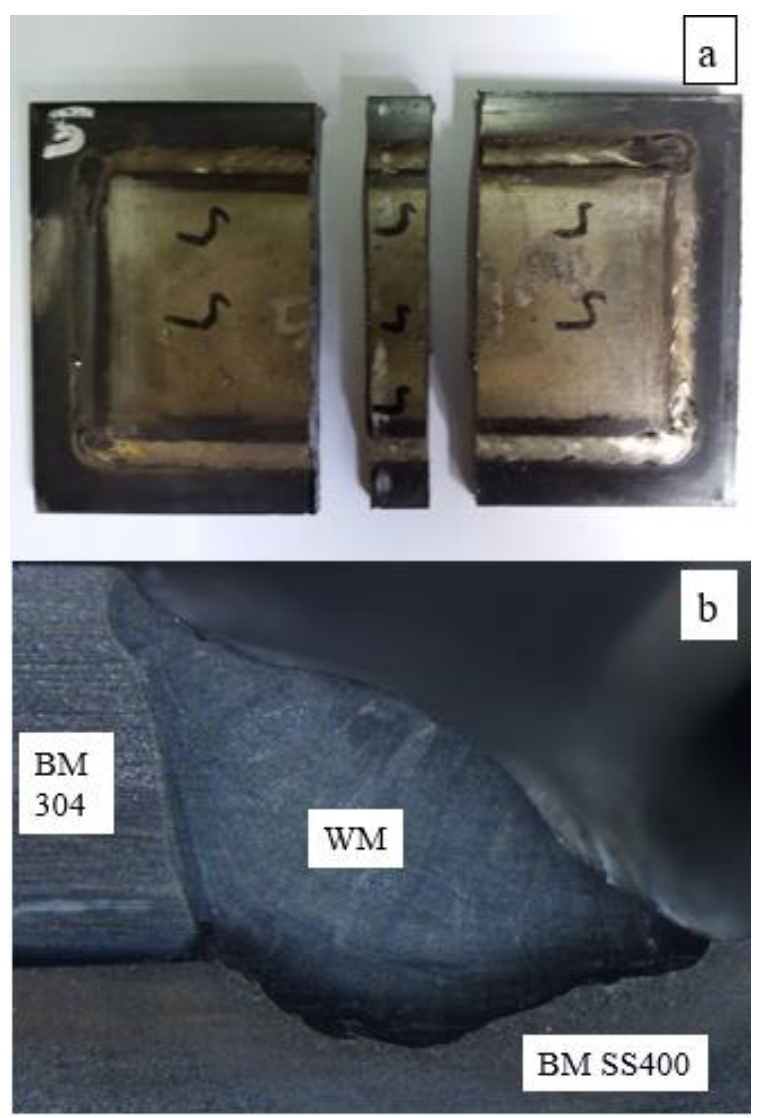

Figure 1. Photograph of dissimilar lap joint: a) cut-section of welded sample, b) macrograph of weld cross section

Table 2. The specimens with different filler metal type and shielding gas

\begin{tabular}{cccccccc}
\hline $\begin{array}{c}\text { Sample } \\
\text { No. }\end{array}$ & $\begin{array}{c}\text { Filler } \\
\text { metal }\end{array}$ & $\begin{array}{c}\text { Diameter of } \\
\text { filler metal } \\
(\mathrm{mm})\end{array}$ & $\begin{array}{c}\text { Shielding gas } \\
\text { composition }\end{array}$ & Current (A) & $\begin{array}{c}\text { Volt } \\
(\mathrm{V})\end{array}$ & $\begin{array}{c}\text { Travel speed } \\
(\mathrm{mm} / \mathrm{min} .)\end{array}$ & $\begin{array}{c}\text { Gas flow } \\
\text { rate } \\
(\mathrm{L} / \mathrm{min} .)\end{array}$ \\
\hline 1 & E316L & 1.2 & $100 \% \mathrm{CO}_{2}$ & $170-180$ & 23 & $320-370$ & 25 \\
\hline 2 & E316L & 1.2 & $90 \% \mathrm{Ar}+10 \% \mathrm{CO}_{2}$ & $170-180$ & 23 & $320-370$ & 25 \\
\hline 3 & E308L & 1.2 & $100 \% \mathrm{CO}_{2}$ & $160-165$ & 23 & $320-370$ & 25 \\
\hline 4 & E308L & 1.2 & $90 \% \mathrm{Ar}+10 \% \mathrm{CO}_{2}$ & $160-165$ & 23 & $320-370$ & 25 \\
\hline 5 & E309L & 1.2 & $100 \% \mathrm{CO}_{2}$ & $160-165$ & 23 & $320-370$ & 25 \\
\hline 6 & E309L & 1.2 & $90 \% \mathrm{Ar}+10 \% \mathrm{CO}_{2}$ & $160-165$ & 23 & $320-370$ & 25 \\
\hline
\end{tabular}

\section{RESULTS AND DISCUSSIONS}

1. Microstructure of Weldments

Figure 2-4 display microstructures of weldments that produced by FCAW using three types of filler metals (E316L, E308L and E309L) and two types of shielding gases $\left(100 \% \mathrm{CO}_{2}\right.$ and $\left.90 \% \mathrm{Ar}+10 \% \mathrm{CO}_{2}\right)$. Figure 2 shows the microstructure of weldment made with E316L filler metal and two different shielding gases: $100 \% \mathrm{CO}_{2} \quad$ (2a) and $90 \% \mathrm{Ar}+10 \% \mathrm{CO}_{2}(2 \mathrm{~b})$. Figure 3 and 4 show the microstructures of weldment made with E308L and E309L respectively. The magnification of the optical microscope for this observation is 
200×. Microstructure of the HAZ-304 consists of the austenite grains as shown in Figure 2-4. Microstructure examinations also revealed the formation of martensite at the HAZ-SS400 present in all the six weldments. Martensite phase developed could be probably due to higher cooling rate after welding. The microstructure of WM is austenite which consists of columnar and cellular. Columnar dendritic sub-structures dominantly was found at the WM-E308L, while the WM-E316L and WM-E309L consist of dendritic and cellular sub-structures. The microstructure observation in the interface of WM (E316L, E308L and E309L) and BM-304 showed epitaxial growth where the grain growth of weld metal is perpendicular to fusion line. It's comparable to earlier study by A.H. Saedi et al. (Saedi, Hajjari, and Sadrossadat 2018) who investigated DMW of AISI 310 stainless steel and HSLA steel welded by TIG welding. Dendritic structure was present probably due to high nickel amount at this region (Reddy et al. 2014). Dendritic substructures are associated with greater segregation and crack susceptibility (Sireesha et al. 2000). This microstructure evolution leads the mechanical properties.

(a)

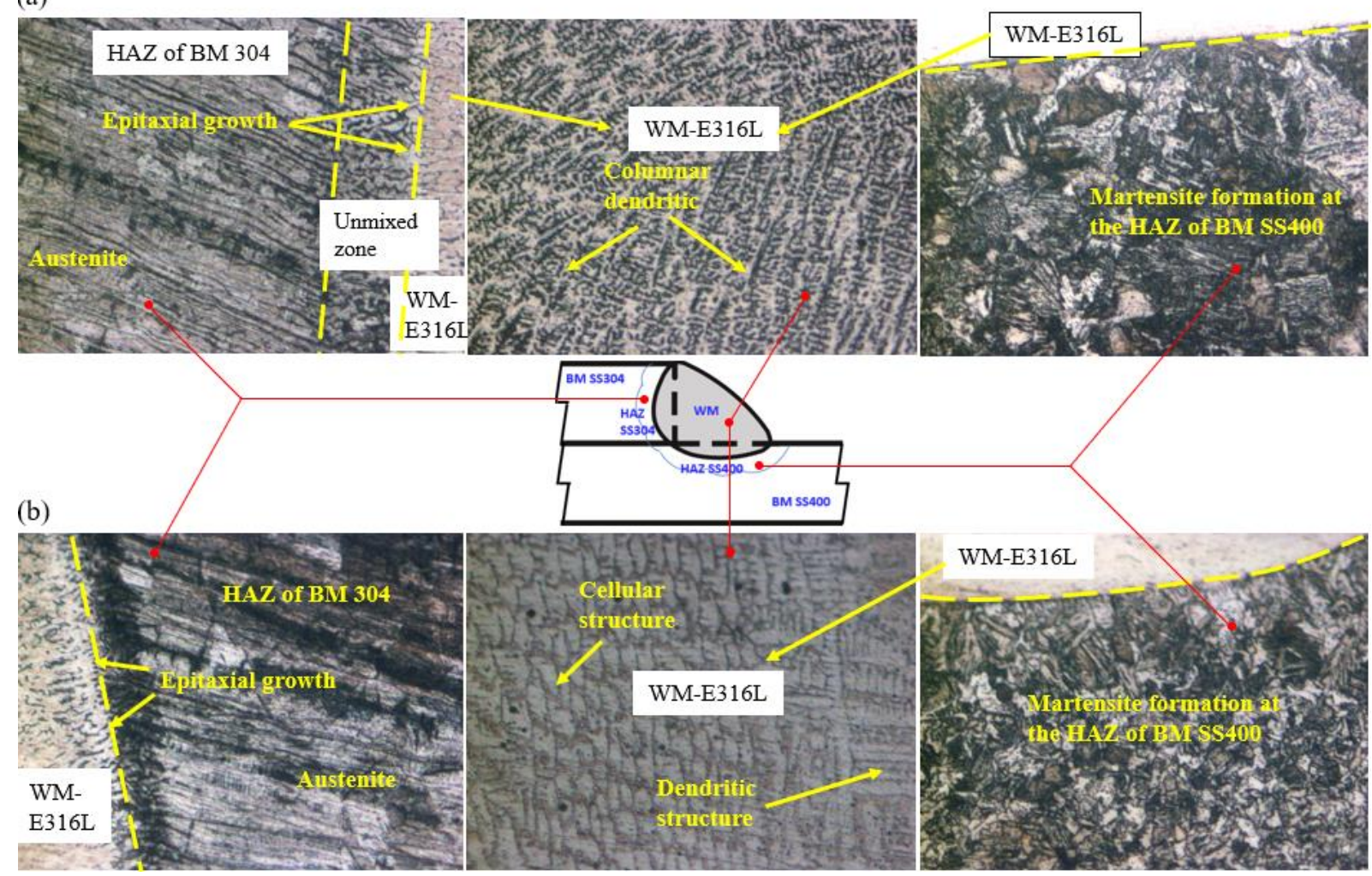

Figure 2. Microstructure of HAZ-304, WM and HAZ-SS400 with E316L filler metal and shielding gas of : a) $100 \% \mathrm{CO}_{2}$ and b) $90 \% \mathrm{Ar}+10 \% \mathrm{CO}_{2}$. Etched in $2 \%$ nital solution $\left(2 \mathrm{ml} \mathrm{HNO}_{3}+98 \mathrm{ml}\right.$ etanol $)$ for SS400 base metal, and marble solution $\left(10 \mathrm{gr} \mathrm{CuSO}_{4}+50 \mathrm{ml} \mathrm{HCl}+50 \mathrm{ml} \mathrm{H}_{2} \mathrm{O}\right)$ for 304 base metal and WM. 200× 
(a)

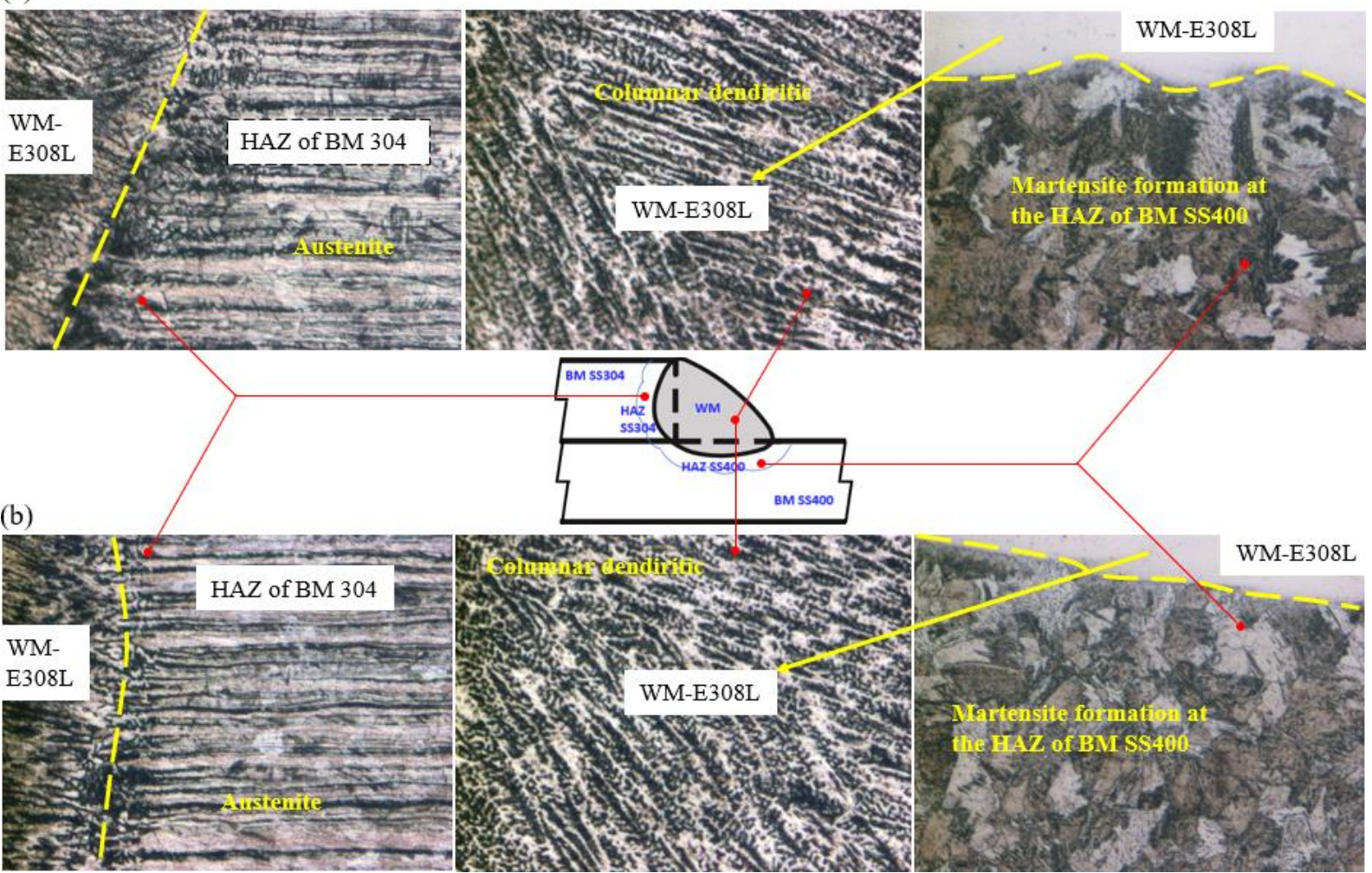

Figure 3. Microstructure of HAZ-304, WM and HAZ-SS400 with E308L filler metal and shielding gas of: a) $100 \% \mathrm{CO}_{2}$ and b) $90 \% \mathrm{Ar}+10 \% \mathrm{CO}_{2} .200 \times$

(a)

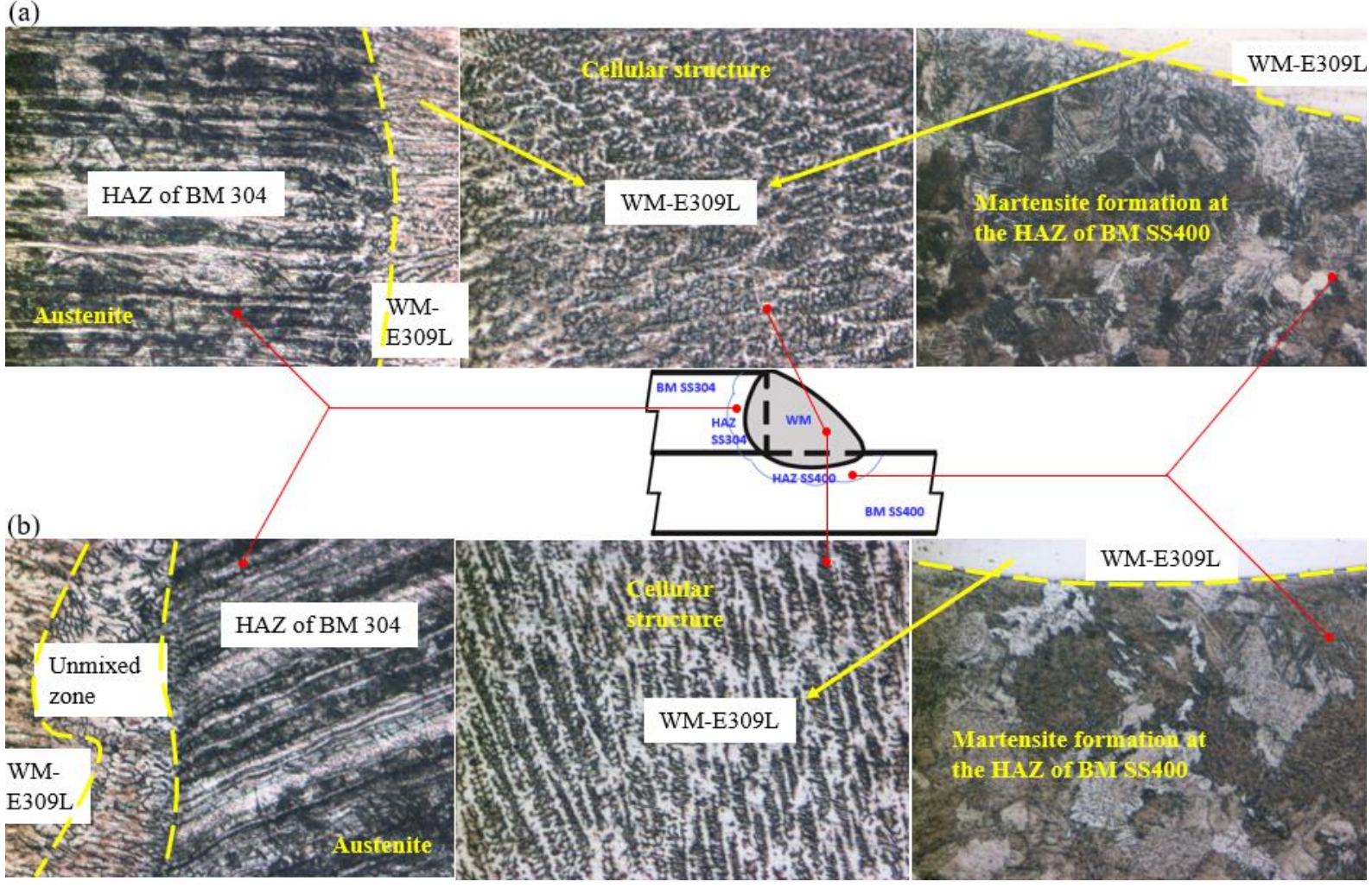

Figure 4. Microstructure of HAZ-304, WM and HAZ-SS400 with E309L filler metal and shielding gas of: a) $100 \% \mathrm{CO}_{2}$ and b) $90 \% \mathrm{Ar}+10 \% \mathrm{CO}_{2} .200 \times$ 


\section{Hardness Profiles}

The hardness profiles of each welded specimens are shown in Figure 6. These microhardness tests results were plotted as the hardness against indentation points on each region (Figure 5). It can be seen clearly that all six welded specimens display the hardness profile of both HAZ-304 and HAZ-SS400 are higher than their BM. The HAZ-SS400 exhibits formation of martensites which provides higher hardness than BM-SS400. The hardness of HAZ-304 is higher than BM-304, it may be attributed to the presence of the fine grains in HAZ-304 due to high temperature during welding operation. R.S Vidyarthy et al. (Vidyarthy, Kulkarni, and Dwivedi 2017) suggested the hardness of HAZ stainless steel was higher than BM stainless steel due to the agglomeration of $\delta$-ferrite stringers.

The WM in all specimens exhibit the higher hardness compared to BM even the austenitic filler metals were employed, it could be attributed to the slightly increased carbon in WM as reported by M. Sireesha et al. (Sireesha et al. 2000). The average hardness value of WM is in between BM and HAZ, except the WME308L which shows a significant difference in the hardness profile compared to WM-E309L and WM-E316L.

The higher hardness values in the HAZ304 can be attributed to chromium carbide precipitation developed during welding operation (Costanza, Sili, and Tata 2016). On the other hand, the higher hardness values in the HAZ-SS400 would be due to martensite formation as investigated by other researchers (Reddy et al. 2014).

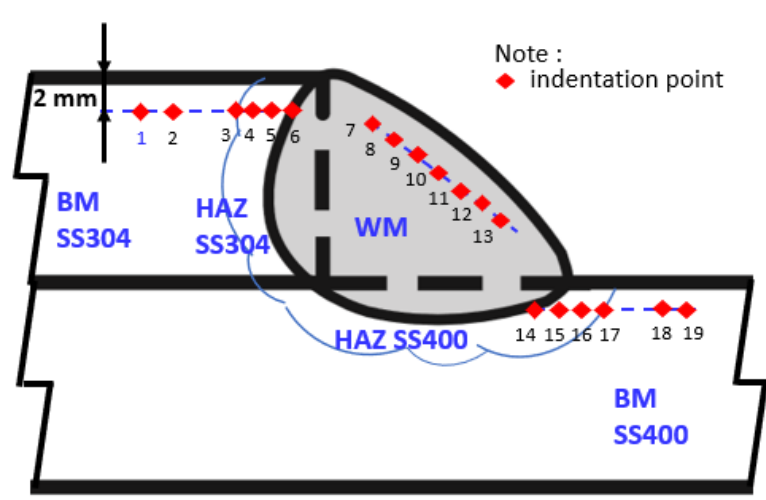

Figure 5. The indentation points layout

Shielding gas composition shows a slightly affects to the hardness of WM. Hardness of WM-E316L that produced with $100 \% \mathrm{CO}_{2}$ shielding gas was 229-232 $\mathrm{HV}$, compared to hardness that using $90 \% \mathrm{Ar}+10 \% \mathrm{CO}_{2}$ was $230-240 \mathrm{HV}$. Hardness of WM-E309L that produced with $100 \% \mathrm{CO}_{2}$ shielding gas was 205-226 HV, it's lower compared to hardness that using $90 \% \mathrm{Ar}+10 \% \mathrm{CO}_{2}$ was $220-240 \mathrm{HV}$. Similar result reported by R Yilmaz et al. (Ramazan and Tümer 2013) who investigated DMW of AISI 316L austenitic stainless steel to AH36 carbon steel welded by FCAW using E309L filler metal. It was observed that hardness of WM that produced with $100 \% \mathrm{CO}_{2}$ is lower than $\mathrm{WM}$ that produced with $88 \% \mathrm{Ar}+12 \% \mathrm{CO}_{2}$. Higher $\mathrm{CO}_{2}$ amount in shielding gas affects to decrease $\delta$ ferrite amount in weld metal so that the hardness decreased. It can be concluded that hardness of $\mathrm{WM}$ that using $100 \% \mathrm{CO}_{2}$ shielding gas was lower than using $90 \% \mathrm{Ar}+10 \% \mathrm{CO}_{2}$. When $\mathrm{CO}_{2}$ amount increases in the shielding gas, austenitic area in the WM was widened, ferrite percentage decreased and dendritic structure become coarser (Katherasan, Sathiya, and Raja 2013). 


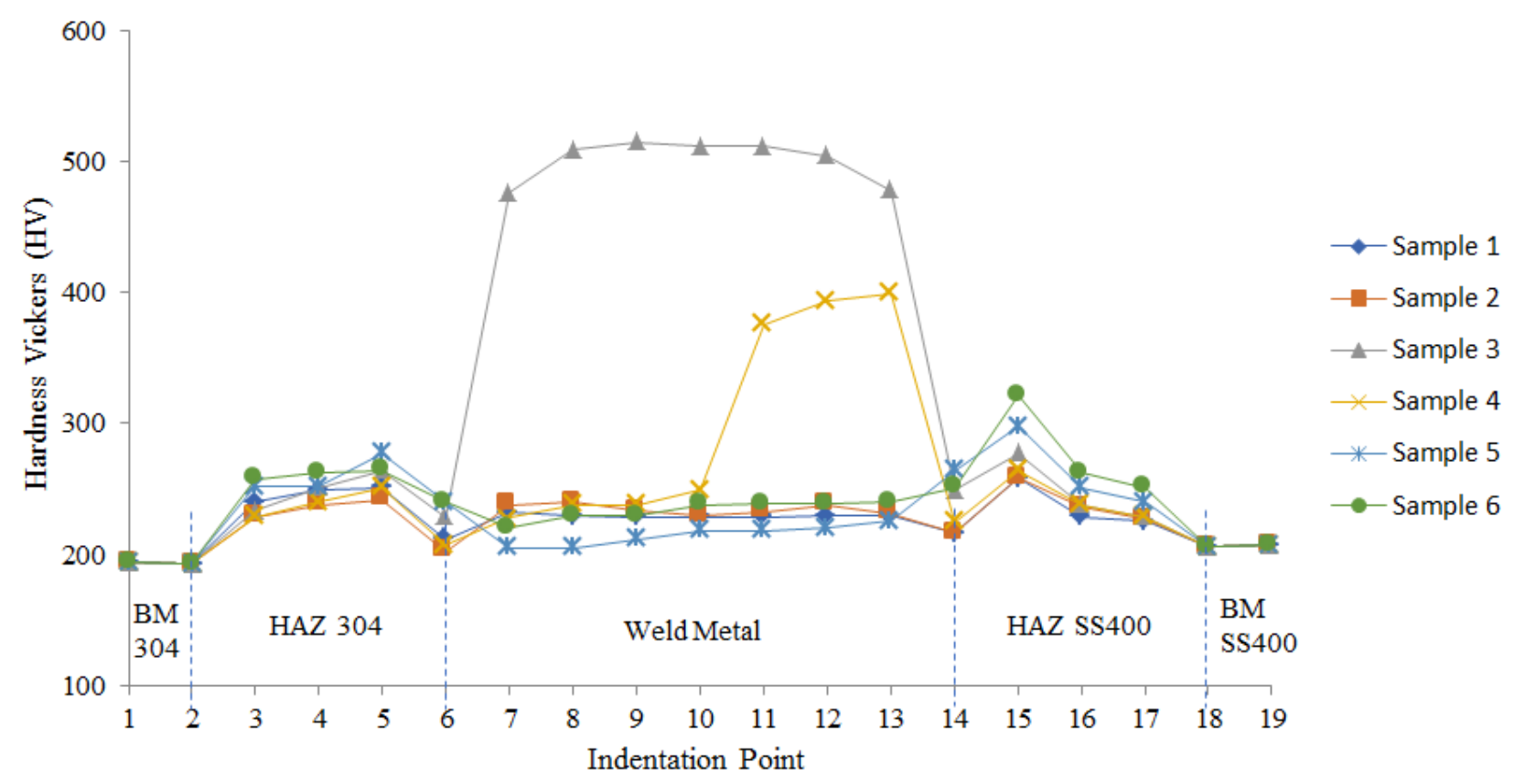

Figure 6. Hardness profile of each specimen

\section{CONCLUSIONS}

1. Selection of appropriate filler metal is a keypoint which influence mechanical properties. Type E308L filler metal produce high hardness in WM compared to E309L and E316L. The high $\mathrm{Cr}_{\mathrm{eq}} / \mathrm{Ni}_{\mathrm{eq}}$ of E308L may attributed to formation of $\delta$ ferrite which influence the hardness. $\mathrm{Cr}_{\text {eq }} / \mathrm{Ni}_{\text {eq }}$ is related to chemical composition of the filler metal which deposited to WM. WM with hard phase has brittle structure so that using type E308L has a greater degree of cracking in WM than using E309L and E316L.

2. The different shielding gas composition shows has not clearly affects the hardness of WM.

3. All six welded specimens display the hardness profile of both HAZ-304 and HAZ-SS400 are higher than their BM. The HAZ-SS400 exhibits formation of martensites which provides higher hardness than BM-SS400. The hardness of HAZ-304 is higher than BM-304, it may be attributed to the presence of the fine grains in HAZ304 due to high temperature during welding operation. The microstructure of both HAZ-304 and WM show austenitic, with columnar and cellular sub-structures present at WM.

4. Hardness of HAZ-304 that welded using $100 \% \mathrm{CO}_{2}$ shielding gas is higher than HAZ-304 that using mixture
$90 \% \mathrm{Ar}+10 \% \mathrm{CO}_{2}$ shielding gas. It may shielding gas that using higher $\mathrm{CO}_{2}$ contributed to form the hard phases in 304 side. However, HAZ-SS400 is unaffected by shielding gas content.

\section{REFERENCES}

Costanza, Girolamo, Andrea Sili, and Maria Elisa Tata. 2016. "ScienceDirect ScienceDirect Weldability of Austenitic Stainless Steel by Metal Arc Welding with Different Shielding Gas ThermoMechanical Modeling of a High Pressure Turbine Blade of an , Gas Airplane Turbine Engine." Procedia Structural Integrity $\quad 2: \quad 3508-14$. https://doi.org/10.1016/j.prostr.2016.06.4 37.

Hajiannia, I, M Shamanian, and M Kasiri. 2013. "Microstructure and Mechanical Properties of AISI 347 Stainless Steel / A335 Low Alloy Steel Dissimilar Joint Produced by Gas Tungsten Arc Welding." Materials and Design 50: 566-73. https://doi.org/10.1016/j.matdes.2013.03. 029.

Hosseini, H Shah, M Shamanian, and A Kermanpur. 2016. "International Journal of Pressure Vessels and Piping Microstructural and Weldability Analysis of Inconel617 / AISI 310 Stainless Steel Dissimilar Welds." International Journal of Pressure Vessels and Piping 144: 18- 
24.

https://doi.org/10.1016/j.ijpvp.2016.05.00 4.

Katherasan, D, P Sathiya, and A Raja. 2013. "Shielding Gas Effects on Flux Cored Arc Welding of AISI 316L ( N ) Austenitic Stainless Steel Joints." Materials and Design 45: 43-51. https://doi.org/10.1016/j.matdes.2012.09. 012.

Mortezaie, A, and M Shamanian. 2014. "International Journal of Pressure Vessels and Piping An Assessment of Microstructure , Mechanical Properties and Corrosion Resistance of Dissimilar Welds between Inconel 718 and 310S Austenitic Stainless Steel.” International Journal of Pressure Vessels and Piping 116: 37-46. https://doi.org/10.1016/j.ijpvp.2014.01.00 2.

Ramazan, Y, and Mustafa Tümer. 2013. "Microstructural Studies and Impact Toughness of Dissimilar Weldments between AISI $316 \mathrm{~L}$ and AH36 Steels by FCAW," 1433-47. https://doi.org/10.1007/s00170-0124579-0.

Reddy, Madduru Phanindra, A Aldrin Sam William, M Mohan Prashanth, S N Sabaresh, K Devendranath Ramkumar, N Arivazhagan, and S Narayanan. 2014. "Assessment of Mechanical Properties of AISI 4140 and AISI 316 Dissimilar Weldments." Procedia Engineering 75: 29-33.

https://doi.org/10.1016/j.proeng.2013.11. 006.

Saedi, A H, E Hajjari, and S Mohsen Sadrossadat. 2018. "Microstructural Characterization and Mechanical Properties of TIG-Welded API 5L X60 HSLA Steel and AISI 310S Stainless Steel Dissimilar Joints." Metallurgical and Materials Transactions A 49 (11): $5497-$ 5508. https://doi.org/10.1007/s11661018-4890-y.

Sireesha, M, V Shankar, Shaju K Albert, and S Sundaresan. 2000. "Microstructural Features of Dissimilar Welds between 316LN Austenitic Stainless Steel and Alloy 800" 292: 74-82.

Vidyarthy, R S, A Kulkarni, and D K Dwivedi. 2017. "Materials Science \& Engineering A Study of Microstructure and
Mechanical Property Relationships of ATIG Welded P91 - 316L Dissimilar Steel Joint." Materials Science \& Engineering A 695 (April): 249-57. https://doi.org/10.1016/j.msea.2017.04.03 8. 